\title{
Chapter 2 \\ The Shadow Economy: Challenges \\ to Economic and Social Policy
}

\author{
Mihail Arandarenko
}

\subsection{Features of the Shadow Economy}

The shadow economy is a multi-dimensional, multi-faceted phenomenon, which inevitably accompanies formal economies throughout the world. However, its characteristics and dimensions can be vastly different: from relatively benign, stable, and acceptable to extremely destructive to the economic tissue and longterm economic growth. In countries where shadow economies are present to a large extent or where they show upward trends, these informal sectors are invariably a symptom of deeper disturbances in the economic structure, regulation, and institutions.

In an environment dominated by the economic crisis-present in Serbia since 2008 both statistically and, particularly, in the public's perception-the need to deeply understand the shadow economy and find ways to reduce it through formalisation grows acute. In times of crisis it becomes more apparent that the shadow economy can be not only a consequence but also a cause of greater decline in the gross domestic product, and can spread the crisis further. The shadow economy becomes part of a vicious circle where one of the consequences of recession is flight from formal to shadow trading, which reduces tax revenue, thus increasing the fiscal deficit. The growing deficit must, in turn, be compensated for by higher tax rates: higher taxes drive more companies and workers into the shadow economy, or, even more devastatingly, out of the economy altogether. This downward spiral keeps repeating itself, always at a lower level of GDP and employment. The empirical mechanisms behind this vicious circle are complex, and include the impact of inflation, declining real wages, and growing unemployment on the increase of the informal economy, and vice versa.

\footnotetext{
M. Arandarenko $(\bowtie)$

Faculty of Economics, University of Belgrade, Belgrade, Serbia

e-mail: arandarenko@ekof.bg.ac.rs 
On the other hand, in an abstract economic context the shadow economy can be viewed as a specific market 'anti-institution'. In this light it can be claimed that the shadow economy can eliminate tax and other wedges that institutions create between labour supply and labour demand or product supply and product demand, thereby creating employment or products that would otherwise not have been created, and extending the cost-effectiveness margin for both individuals and businesses.

In a hypothetical market free of taxes and other costs associated with the running of institutions, all economic activity is 'in the shadow'. In reality, formal and informal economies exist in parallel, which introduces distortions and allocates resources sub-optimally. Schneider and Enste (2000) underline the ambivalence of the effects of the shadow economy on the formal economy. On the one hand, the informal economy leads to allocation distortions because resources and production factors are not used as efficiently as possible. On the other hand, income generated in the shadow economy is mainly spent in the formal economy (as much as threequarters, according to surveys carried out in Germany), which has a stimulating effect on it.

In order to be efficient, measures designed to foster the formalisation of the shadow economy have to be based on knowledge of the causes and structure of informal activity. A particular problem in designing these measures is that information about the shadow economy is necessarily unreliable and incomplete. Further, the shadow economy is inherently very heterogeneous, while economic policy measures, to be implementable in practice, should be simple and, in the main, universally applicable — at any rate, less selective than is desirable from the point of view of optimal targeting.

From the standpoint of economic and social effects, and given the need to develop a formalisation strategy for the shadow economy, it is very important to have a clear perspective of the dominant character of the shadow economy in any particular country and to know whether it is primarily a consequence of voluntary or forced exit, or of exclusion. Voluntary exit means that particular individuals, with specific preferences and mind-sets (say, strong individualists or people more likely to take risks), decide to engage in economic activity outside of the formal economy, even though they are able to find employment in the formal sector. Voluntary exit from the formal economy with the aim of maximising profits or personal income can be reinforced by inadequate penal policy or the lack of implementation of legal sanctions. Forced exit means that individuals or firms are pressured to leave the formal economy due to their own failure in the market, negative trends in the business environment, or rigid regulation. For these entities the shadow economy is the last resort. Exclusion means that certain individuals or groups have never been part of the formal economy, nor have ever had any realistic opportunity to join it.

The two main groups of entities engaged in the shadow economy are businesses and the population. 'Diagnosing' the shadow economy, as a precondition for successfully tackling it, entails answering many specific structural questions that relate to both of these large groups of stakeholders. It is important to learn more 
about the levels of education and human capital of the segments of the population that participate in the shadow economy, as well as their geographical distribution and structure by type of locality (urban/rural population), structure by age, gender, and social status, the average amount and distribution of wages in the shadow economy, and working hours and modes of employment (primary vs. secondary or supplementary).

Detailed structural information is also needed on businesses and entrepreneurs. These include both basic data (total revenue, profit, number of employees, industry, registration status, etc.) and information on participation in the shadow economy, ranging from evasion of taxes and other dues payable to the state, to non-compliance with regulations and standards that entail expenses.

More information is available on the participation of the population in the Serbian shadow economy than on businesses, owing to regular semi-annual Labour Force Surveys carried out by the Statistical Office of the Republic of Serbia. The survey implemented in this study, aimed primarily at businesses and entrepreneurs, will therefore fill a major void in the available knowledge base for pursuing evidence-based economic and social policies designed to formalise the shadow economy.

\subsection{Brief History of the Shadow Economy in Serbia}

Over the last quarter of a century Serbia's economy has undergone tectonic changes. In the late 1980s the economic system was still based on socialist selfmanagement, rooted in self-managing socially owned businesses. There was a shadow economy, but it was confined to the then-small private sector and households, mainly in agriculture and through supplementary work. This situation underwent fundamental change from the early $1990 \mathrm{~s}$ as the federal state disintegrated: business legislation was amended in the 'first transition' while initial privatisation took place; hyperinflation ravaged the country between 1992 and 1994; international sanctions were introduced in 1992 — with Serbia virtually living in a state of war. All of these factors contributed to the creation of a lawless business environment in which the shadow economy flourished. In the 1990s even the central authorities operated informally in many important aspects of the economy such as customs and foreign trade. The parallel existence of private, social, and state property stimulated a great deal of abuse. Faced with loss of income or even property, households turned in large numbers to the shadow economy as their primary or supplementary source of income. Workers, although generally retaining formal jobs, nonetheless lost reasonable or indeed any wages, and supplemented them by finding employment in the shadow economy. Many businesses also turned to the shadow economy, with socially owned companies largely evading the payment of payroll taxes, while the newly established private firms often evaded taxes and failed to declare their employees. Parallel trade in consumer goods, particularly those subject to excise duty, reached extreme levels. 
Estimates of the extent of the shadow economy in the 1990s on the one hand show extremely high levels and on the other substantial volatility. The halting of hyperinflation in 1994 and the removal of most of the sanctions imposed by the international community resulted in a drop in the volume of the informal economy after the 1993 peak when the share of the shadow economy reached $54.4 \%$ of GDP. In 1995 this figure declined to $40.8 \%$, and fell again to $34.5 \%$ in 1997 (Krstić et al. 1998). In all likelihood the relative size of the shadow economy grew again after the bombing campaign against Serbia in 1999.

Macroeconomic stabilisation and economic reforms, including European integration, begun after the ousting of the Milošević regime in 2000, had been expected to bring about a quick decline in the extent of the shadow economy. This, however, failed to materialise, both in terms of the reduction seen and the time it took for improvements to take place. There are several potential explanations for this. Firstly, the period after 2000 was marked by accelerating transition, including mass privatisation and restructuring, which introduced additional instability. Secondly, there are strong arguments in favour of the claim that inappropriate taxation policy, particularly in the field of labour taxation, ${ }^{1}$ incentivised flight into the informal sector rather than the formalisation of businesses and employment. Further, inefficient and selective law enforcement was the hallmark of this entire period, which again failed to create sufficient incentives for entities to leave the shadow economy.

Yet it cannot be disputed that the 2000s saw changes in the relative size and character of the shadow economy. The development of the shadow economy over the last decade has been studied more extensively from the point of view of households than from that of businesses. It can be monitored through the three waves of the Living Standards Measurement Study (2002, 2003, 2007) and, since 2008, through semi-annual Labour Force Surveys as well.

Informal employment can be defined in various ways. Basically, people working without formal contracts and unable to exercise their social insurance rights are employed informally. They may work for a wage, be self-employed, or work as helping members of households-with this last category being informal by definition.

Krstić and Sanfey (2011) compared data on informal employment obtained from the Living Standards Measurement Survey at two points in time, 2002 and 2007, which correspond to the early and mature phase, respectively, of Serbia's post-2000 transition. By their own admission, they obtained counterintuitive results that indicate that the level of informal employment increased significantly over those 5 years, from $28 \%$ of total employment in 2002 to $35 \%$ in 2007. Secondly, they also found that the informal nature of employment was a significant determinant of inequality in 2007, but not so in 2002 - in other words, transition saw a 'dipping' of

\footnotetext{
${ }^{1}$ This primarily refers to the very high tax burden at low wage levels, which resulted in very high average and marginal tax rates for the minimum wage, the natural point of entry into the formal economy. This issue will be dealt with in greater detail in Chap. 3 .
} 
informal employment towards the bottom of the wage distribution, in parallel with the growth in its volume. Thus the authors found that informal workers earned less than formal workers in monthly net amounts, even when all other characteristics were controlled for. In an endeavour to discover the potential causes of the increase in informal employment and the rise in the advantage enjoyed by the wages of formal workers, the authors point to the regressive labour taxation system as one of the likely causes of these unexpected and unfavourable trends.

Although the Labour Force Survey as carried out prior to 2008 did not contain questions that would enable employment to unambiguously be categorised into one of two mutually exclusive categories - formal or informal — efforts were made to estimate informal employment using Labour Force Survey data. Thus, under a World Bank (2006) classification, the group of those in informal employment includes: (1) self-employed people without a university degree; (2) all helping members of households; and (3) salaried employees and owners of private companies with fewer than ten staff. All salaried employees of state and socially owned businesses are deemed to be formally employed. According to the definition used in this World Bank report, Serbia's informal sector was very large in 2005, comprising $43 \%$ of all those in employment and $27 \%$ of all salaried employees. Although informal economy is overestimated by the arbitrary inclusion of the micro-business and entrepreneurs in the informal economy, the structural findings are distinctive and for the most part convincing, and are also borne out by other analyses. The study also found that informal employment is linked to low income, poverty, and vulnerability. Further, there is an above-average share of the young and the undereducated among those in informal employment. Professional experience and wages are much lower in the informal than in the formal economy. The wage premium for those in formal work stood at around $20 \%$.

Interestingly, data from the 2008 Labour Force Survey show much lower levels of informal employment than those presented above. Another interesting finding, available since the Labour Force Survey made it possible to monitor informal employment, is that informal employment was slower to decline during the crisis. Thus, as shown in Table 2.1, the share of informal employment in total adult employment according to the 2008 Labour Force Survey stood at $23 \%$. This figure dropped to $21 \%$ in 2009 , fell again to $19.6 \%$ in 2010 , only to decline yet again to just $17 \%$ by April 2012.

It should be borne in mind that, under the definition used by the Statistical Office of the Republic of Serbia, informal employment includes: (1) workers at unregistered privately held companies; (2) workers at registered companies employed without a written contract and without paid social insurance contributions; and (3) helping family members. Krstić (2012) uses a more standard definition, which also includes workers employed under a written contract but without paid contributions. Consequently, this study found greater rates of informal employment, as shown in Table 2.2.

A finding of this study, which is both interesting and difficult to explain, is the substantial decline in informal work seen since the start of this crisis. It does not fit 
Table 2.1 Serbia: Labour market and informal employment indicators, 2006-2012

\begin{tabular}{l|l|l|l|l|l|l|l}
\hline & 2006 & 2007 & 2008 & 2009 & 2010 & 2011 & 2012 \\
\hline Participation rate (\%) & 63.6 & 63.4 & 62.7 & 60.6 & 59.0 & 59.9 & 59.7 \\
\hline Employment rate (\%) & 49.8 & 51.5 & 53.7 & 50.4 & 47.2 & 45.3 & 44.2 \\
\hline Unemployment rate (\%) & 21.6 & 18.8 & 14.4 & 16.9 & 20.0 & 24.4 & 26.1 \\
\hline $\begin{array}{l}\text { Informal employment (in \% of population } \\
\text { aged 15 years and over) }\end{array}$ & - & - & 23.0 & 20.6 & 19.6 & 17.8 & 17.0 \\
\hline
\end{tabular}

Source: Labour Force Survey, Statistical Office of the Republic of Serbia

Table 2.2 Informal employment based on broader definition, October 2010-October 2011

\begin{tabular}{l|l|l|l}
\hline & $\begin{array}{l}\text { October } \\
2010\end{array}$ & $\begin{array}{l}\text { April } \\
2011\end{array}$ & $\begin{array}{l}\text { October } \\
2011\end{array}$ \\
\hline $\begin{array}{l}\text { Informal employment (in \% of total employment, } \\
\text { 15+) }\end{array}$ & 25.8 & 25.1 & 24.1 \\
\hline $\begin{array}{l}\text { Informal employment (in \% of total employment, } \\
\text { 15-64) }\end{array}$ & 23.1 & 22.5 & 21.8 \\
\hline Informal employment outside agriculture & 9.2 & 9.5 & 8.5 \\
\hline
\end{tabular}

Source: Krstić (2012); Estimates based on panel observations. Labour Force Survey, Statistical Office of the Republic of Serbia

into the standard assumption of the counter-cyclical or at least ambivalent character of informal employment.

A newer comparative study carried out by the International Labour Organisation (ILO 2011) found that Serbia had the lowest level of non-agricultural informal employment among a group of 44 mostly middle- and lower-income countries. Data for Serbia were collected using the Labour Force Survey, which, it was recently claimed, has categorisation issues that probably make it underestimate the actual number of those in informal employment (Krstić 2012). Nevertheless, the conclusion that the level of non-agricultural informal employment in Serbia is lower than would be expected based on its GDP is certainly valid-placing Serbia among countries with relatively low levels of non-agricultural informal employment (ILO 2011).

Be that as it may, research into the informal economy from the population standpoint undoubtedly shows that the informal sector has substantially changed in character over the last decade. Let us note that the standard theoretical explanation for informal employment (at least for salaried employment) is that both the employee and the employer have an interest in splitting the 'excess' that appears when the payment of social contributions is evaded. In this context, an informal wage is greater than a salary in addition to which contributions must be paid, but, in terms of total labour costs, it is lower than the total labour costs of a formal salary. While at the beginning of the decade the informal sector, obviously taking its cue from the disorderly 1990s, comprised employees with widely varying and not necessarily inferior characteristics, who did not earn less than their formal counterparts (see, for instance, the findings of Lokshin and Jovanović 2003), by the end 
of the 2000s it was no smaller in size but its structure had taken a dramatic turn for the worse, as had its exposure to discrimination and poverty. If this had been a sector of voluntary 'exit' at the beginning of the decade, by its end it had become predominantly a sector of 'exclusion' (cf. Oviedo et al. 2009).

Findings about the volume, structure, and features of informal employment are of great importance in designing economic and social policies aimed at tackling the shadow economy. Data available from the Labour Force Survey, as well as deeper research based on various sources that we have presented in brief, indicate that informal employment is today primarily the last refuge of those forced out of the formal economy during the transition and traditionally excluded groups. Consequently, when developing and implementing measures to formalise informal employment, incentives should take precedence over sanctions.

Why did we need this brief summary of the development of the shadow economy in Serbia? It was needed because it serves as a reminder of the multi-faceted, heterogeneous, and simultaneously stubborn, deeply rooted nature of this phenomenon. In the early 1990s the shadow economy became an acceptable survival mechanism for businesses, entrepreneurs, and households, in answer to the multiple shocks that they faced. At the time, liberal economists mainly underlined the positive role of neo-liberal economics in co-ordinating the market and fostering entrepreneurship. Yet the shadow economy mangled the rules and institutions of the market economy, incentivised corruption, and undermined fiscal morality and the trust of the population in the state. In various forms, the entire society took part in the shadow economy. For instance, the official foreign currency exchange rate usually deviated from the market exchange rate, sometimes even by a multiple of the official figure, but transactions in foreign currency nonetheless took place at the market exchange rate.

The negative economic and social effects of the informal economy first became an issue in the 2000s. Starting in 2001, the Ministry of Finance undertook periodical publicity campaigns to raise the profile of tax compliance, particularly that accompanying the introduction of VAT and fiscal receipts. A survey recently carried out by the Employers' Association and the Association of Independent Trade Unions confirmed that business entities generally viewed the informal economy in a negative light.

However, as with many other areas of the economy, government authorities and economic policymakers are yet to systematically tackle this issue. There is no clear commitment or strategy to the fight against the shadow economy. The past decade again saw permitted exceptions that damaged equality of the participants in the formal market: for instance, 'linking' workers' years of service to compensate for unpaid contributions, cancelling back taxes and other arrears, and tolerating the non-payment of social security contributions by public businesses. Socially owned companies in restructuring even enjoyed, for a long period of time, formal statutory protection from actions that might have led to their insolvency (under the latest amendments to the Law on Privatisation, this protection is set to expire in mid-2014), and were thus able to run up huge debts in unpaid employee contributions to social security funds. There were several waves of what is termed "linking 
employees' years of service", where the government pays staff contributions at troubled companies - thereby attempting to sway public opinion, but also acting as accessory to the undermining of fiscal morals. This practice of socialising costs, of course, has a negative demonstration effect on employers who comply with all of their statutory obligations to their staff. In other cases, objectively marginal from the point of view of public interest, the state was extraordinarily efficient, even brutal, when collecting certain dues (e.g., performance rights charges).

Serbia's experience over a lengthy period of time demonstrates the shadow economy's distorting and negative effect on balanced economic growth, particularly in times of economic crisis. Displacement and substitution effects dominate employment trends. To paraphrase Gresham's law, no net new jobs are createdbad jobs just drive out the good ones.

Although current economic conditions are much more favourable than those that prevailed during the last decade of the twentieth century, and the shadow economy shows no signs of overflowing its admittedly broad and comfortable basin, it poses at least a threefold challenge to economic policymakers. Firstly, it directly hurts public finances and often threatens public safety and health. Secondly, it is a symptom of institutional weakness and an unfavourable business environment, which jeopardises long-term growth. Thirdly, although it may at first sight seem to serve as a refuge for vulnerable groups, the shadow economy is in reality a trap, perpetuating instead of eliminating their poverty and exclusion.

Open Access This chapter is distributed under the terms of the Creative Commons Attribution Noncommercial License, which permits any noncommercial use, distribution, and reproduction in any medium, provided the original author(s) and source are credited.

\section{References}

International Labour Office (2011) Statistical update on employment in the informal economy. ILO Department of Statistics

Krstić G (2012) Labour force flows and informal economy in Serbia. In: International conference from global crisis to economic growth. Which way to take? The Faculty of Economics, University of Belgrade, September 2012

Krstić G, Sanfey P (2011) Earnings inequality and the informal economy: evidence from Serbia. Econ Transit 19(1)

Krstić G et al (1998) Analysis of the grey economy in the FRY with estimates of its volume for 1997 and recommendations for its legalisation. Economics Institute Belgrade

Lokshin M, Jovanović B (2003) Wage differentials and state-private sector employment choice in Yugoslavia. Econ Transit 11

Oviedo et al (2009) Economic informality: causes, costs and policies - a literature survey. World Bank Working Paper No. 167, Washington, DC

Schneider F, Enste D (2000) Shadow economies: size, causes and consequences. J Econ Lit 38 (1):77-114

World Bank (2006) Serbia: labor market assessment, report no. 36576-YU, Washington, DC 